\title{
Simple and Economical Method to Create Thoracolumbar Burst Fracture in a Calf Spine Model
}

\author{
Vijay Sekharappa, Azad Sait \\ Spinal Disorder Surgery Unit, Department of Orthopaedics, Christian Medical College, Vellore, India
}

\section{Study Design: Calf spine model study.}

Purpose: To describe a technique of creating thoracolumbar burst fractures in calf spine model by low weight drop weight.

Overview of Literature: Burst fractures are one of the commonest types of thoracolumbar fractures and their treatment is controversial. Biomechanical studies aid in the decision of treatment of these fractures. A simple method of creation of burst fractures would help these biomechanical studies.

Methods: Ten specimens of thoracolumbar spines harvested from 6-8 week old calves were weakened at the target vertebra by standardized osteotomy cuts. Burst fractures were created by dropping a 5-kg of weight from a height of $1.2 \mathrm{~m}$ using an in-house device. An accelerometer attached to the weight measured the acceleration at the point of impact.

Results: Average weight and bone mineral density of the specimens was $390 \mathrm{~g}$ and $0.67 \mathrm{~g} / \mathrm{cm}^{2}$, respectively. Computed tomography scan analysis of the fractures revealed McCormack grade 2 and grade 3 fractures in 5 and 3 specimens, respectively, Dennis type 2B in 4, type 2A burst fractures in 5 specimens and fracture dislocation in 1 specimen, A0 type A3.1.1 in 4 specimens, type A3.2.2 in 4 and type A3.3.3 in 2 specimens. Vertical laminar split fracture was seen in 6 specimens. Average acceleration and energy at impact was $9.04 \mathrm{~m} / \mathrm{sec}$ and $54.24 \mathrm{Nm}$, respectively.

Conclusions: We describe a technique to create thoracolumbar burst fractures in calf spine by a drop weight method using a device that is simple to operate and easy to construct. The method is consistent and produces fractures similar to those occurring naturally, and can be considered as an alternative method for creating burst fractures in biomechanical studies.

Keywords: Spine; Calf; Burst; Fracture

\section{Introduction}

Burst fractures are one of the most common types of fractures encountered in clinical practice, accounting for more than two-thirds of all types of thoracolumbar vertebral fractures [1]. Burst fractures were initially described by Holdsworth [2] and were later classified by Denis [3] as type II and by $\mathrm{AO}$ as type $\mathrm{A} 3$ fractures [1]. As described by Magerl et al. [1], there fractures are caused by axial compression with or without flexion, and are characterized by partial or complete comminution of the vertebral body with retropulsion of posterior wall fragments. The

Received May 12, 2015; Revised Jul 16, 2015; Accepted Jul 16, 2015

Corresponding author: Vijay Sekharappa

Spinal Disorder Surgery Unit, Department of Orthopaedics, Christian medical college,

Vellore, 632004, Tamil Nadu, India

Tel: +91-041-6228-2020, Fax: +91-041-6223-2035, E-mail: vijays_sdumc@yahoo.co.in 
posterior ligamentous complex remains intact and the posterior arch injury, if present, is always a vertical split of lamina, which does not contribute to stability [1]. The treatment of these fractures is controversial and varies from conservative to long posterior or combined anterior and posterior fixation [4]. Biomechanical studies can aid in decision making concerning the treatment of these fractures.

A number of methods have been described for creating burst fractures in vitro, to perform biomechanical studies in both human cadavers and animal spine models. However, many of these methods involve complex devices, are not reproducible or do not mimic the fractures occurring by natural process. Even though the human cadaveric spine is ideal for these studies to produce comparable results with clinical trials, it may not be feasible in many centers because of their limited availability, risk of infection, and ethical and religious issues [5]. Calf spine has been shown to have mechanical and physical properties similar to that of human spine and so is a good substitute for biomechanical studies [6]. Vertebra from calves 6-8 weeks old have bone density and anatomical size similar to that of an adult human vertebra, and so can be ideal specimens for testing in vitro [5].

However, there are subtle differences between the calf and human spine, which include the lower range of flexion and extension of calf spine compared to the human spine [5]. Furthermore, the properties of the end plate in immature calf spine in comparison to the adult spine have not been studied [7]. Because of these differences the technique described for creating burst fractures in human cadaveric spine cannot be directly applied to calf spine.

We describe a simple technique using an inexpensive and easily constructible device producing a burst fracture in an immature calf spine model that is easily reproducible and mimics the fracture occurring naturally.

\section{Study design}

Calf spine model study.

\section{Materials and Methods}

Ten specimens of thoracolumbar spine were acquired from 6-8 week old calves at a local slaughter house. Specimens were prepared so that each specimen consisted of five vertebrae from the second-last thoracic to third lumbar vertebra with disco-ligamentous structures. The specimens were dissected off the muscles and separated from the ribs to preserve the ligaments. They were stored by freezing at $-4^{\circ} \mathrm{C}$. Plain radiographs and computed tomography (CT) scan of the specimens were taken to rule out any bony pathology and bone mineral density (BMD) of each specimen was measured using dual energy X-ray absorptiometry scanning (Fig. 1).

The device for creating the fracture was manufactured
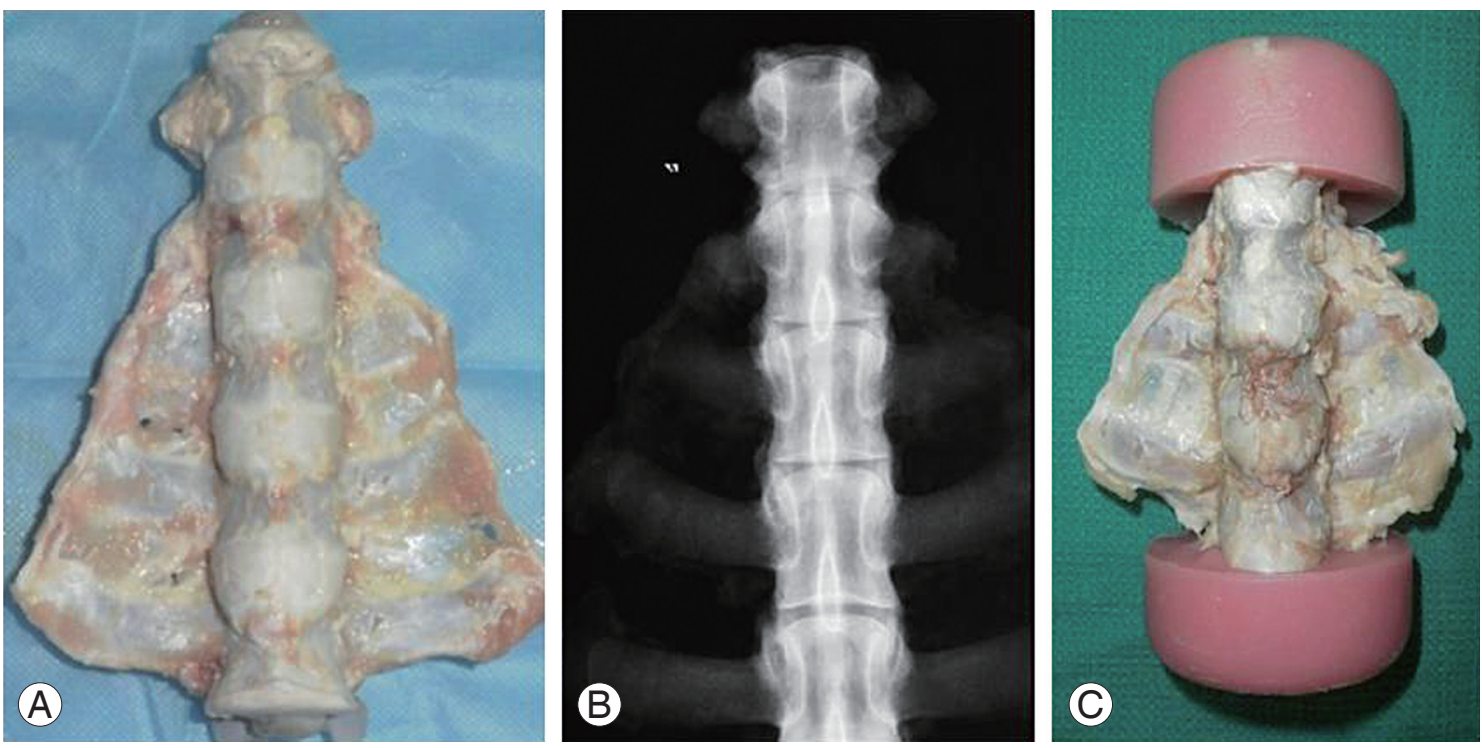

Fig. 1. (A) Calf spine specimen harvested and separated from muscles and ribs preserving discoligamentous structures. (B) X-ray of the specimen (C) specimen after mounting on dental resin. 
at a workshop using locally available materials. It consisted of a rectangular base measuring $0.61 \times 0.61 \mathrm{~m}$ with two parallel cylindrical rods of $3.8 \mathrm{~cm}$ diameter welded to the base. The rods were cross connected on the top using a bar with a cylindrical ring in the center that would allow another cylindrical rod $3.8 \mathrm{~cm}$ in diameter. Through the central ring on the top cross bar, another cylindrical rod of $3.8 \mathrm{~cm}$ diameter was passed through and an hemispherical impactor was attached to the end. This central rod acted as a guide for dropping the weight. A $5-\mathrm{kg}$ weight was allowed to freely glide through this central post and was kept at a height of $1.2 \mathrm{~m}$ using a cross pin. An accelerometer was attached to the weight to calculate the pre-impact acceleration (Fig. 2).

The night before testing, the specimens were thawed in normal saline. Upper and lower vertebra were mounted on dental cement and moulded into cup shapes. The index vertebra was weekend using a $1-\mathrm{cm}$ wide osteotome. The cuts were standardized to all specimens. Three cuts were made: two were anterior posterior and one was mediolateral through the upper end plate. The cuts divided the upper half of the body and upper end plate into six segments. The anterior posterior cuts extended into the posterior cortex, as confirmed by a sensation of giving way. Posterior elements remained undisturbed (Fig. 3).

The specimen was placed over the cylindrical support on the base of the device and fixed firmly by packing with

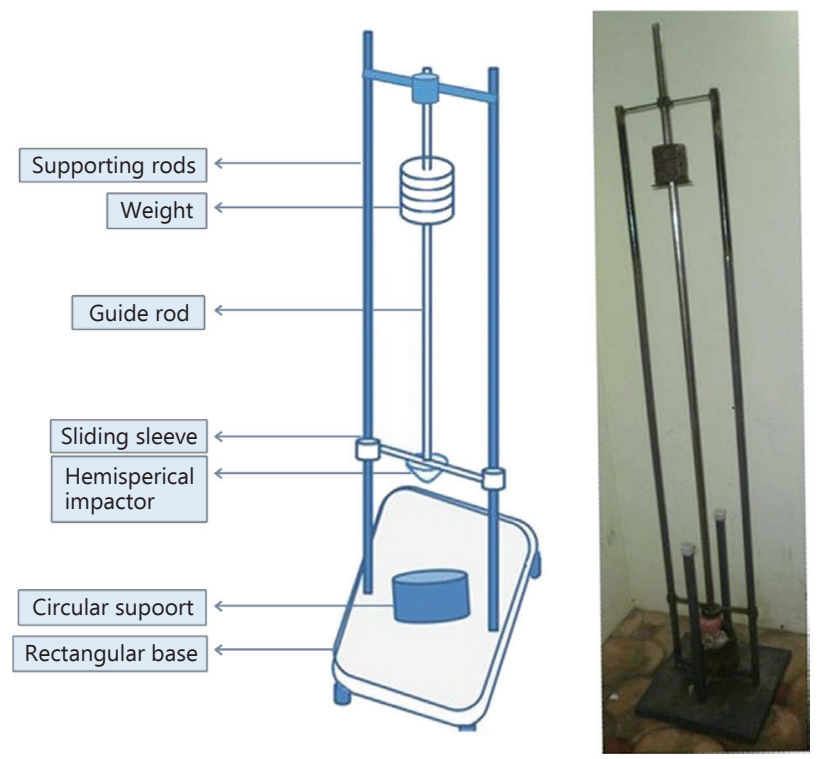

Fig. 2. Diagrammatic representation of the device used for creating burst fracture. non-compressible foam on the sides. The impactor was placed on the upper end of the mounted specimen. The specimen was positioned so that the point of contact of the impactor on the cement mould was anterior to the centre, thereby giving a flexion force when the weight was dropped. The 5-kg weight was dropped from a height of 1.2 $\mathrm{m}$. The device attached to the weight measured the acceleration and the energy transmitted at the point of impact was calculated from the formula $\mathrm{E}=\mathrm{mah}$; where ' $\mathrm{m}$ ' is the weight of the mass dropped ( $5 \mathrm{~kg}$ ), ' $a$ ' is the pre-impact acceleration and ' $h$ ' is the height from which the mass was dropped $(1.2 \mathrm{~m})$.

\section{Results}

The weight of the specimens ranged from 350-460 g with an average weight of $390 \mathrm{~g}$. The average BMD of the specimens was $0.67 \mathrm{~g} / \mathrm{cm}^{2}$. The $5 \mathrm{~kg}$ weight when dropped freely from a height of $1.2 \mathrm{~m}$, produce an average acceleration of $9.1 \mathrm{~m} / \mathrm{sec}$ as recorded by the accelerometer attached to the weight. The average energy at the point impact was calculated to be $54.24 \mathrm{Nm}$ (range, 53.4-54.6 Nm) (Table 1).

CT scan analysis of the fractures revealed partial or complete comminution of the vertebral body in all the specimens with the fracture line extending to the posterior vertebral wall and retropulsion of the fragments with

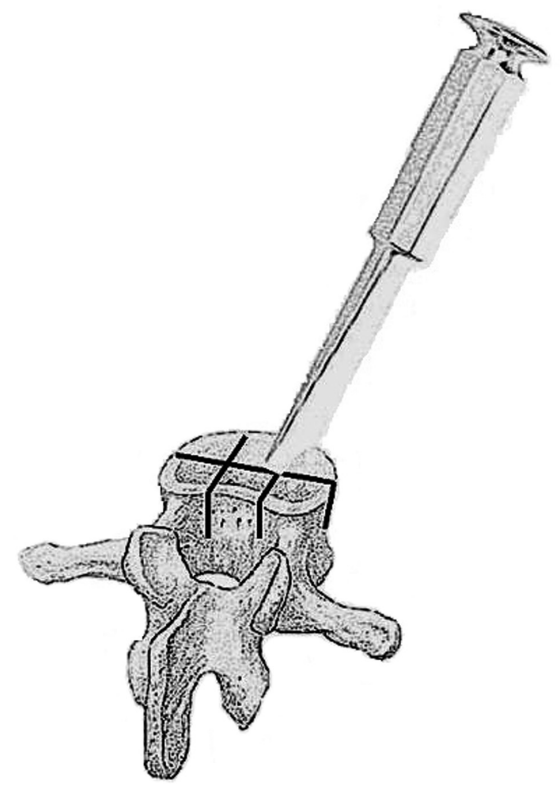

Fig. 3. Diagram showing standardized osteotomy cuts through the upper end plate and upper half of the vertebral body. 


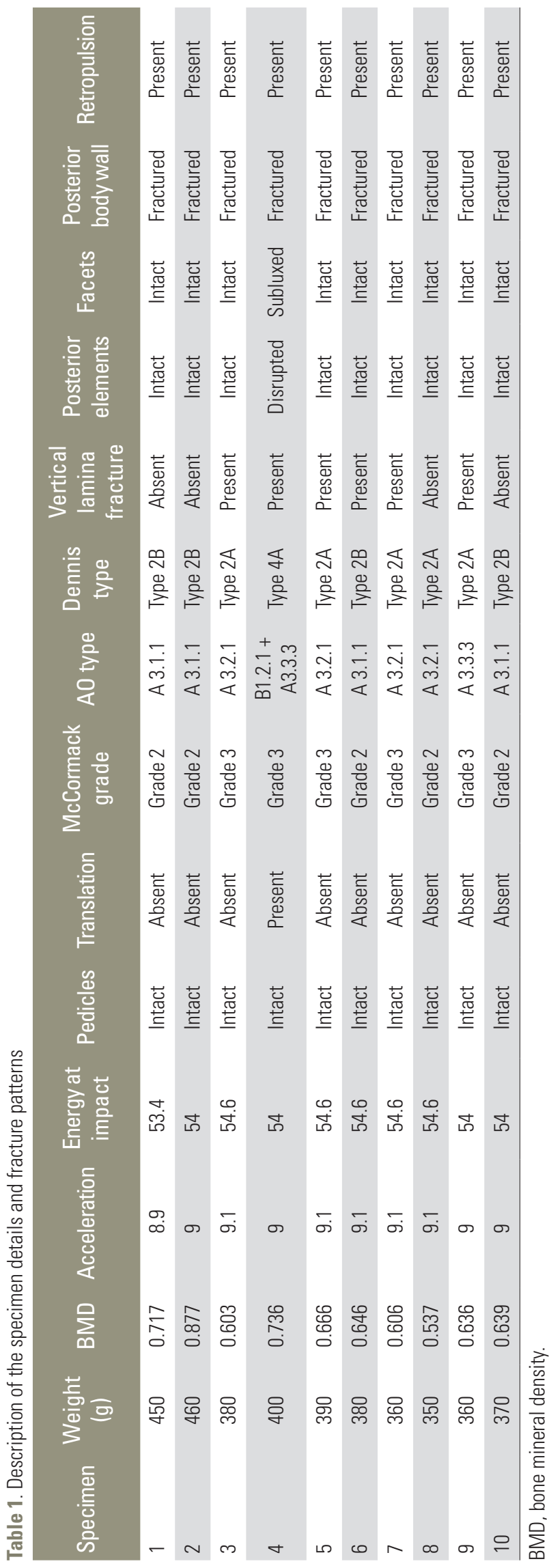

intact pedicles confirming the burst type. Vertical split fractures of the lamina, a characteristic feature of burst fracture [1], was seen in 6 specimens. The facets and the posterior ligamentous complex remained intact in all the specimens, except in specimen 4 . This specimen showed disruption of the posterior ligamentous complex with anterior translation and subluxation of the facets along with comminution of the vertebral body (Figs. 4, 5).

The fractures created were classified by the McCormack, Dennis, and AO standard classification schemes. In McCormack load sharing classification, burst fractures are classified into three grades based on the comminution, opposition and angle of corrected kyphosis [8]. Our technique resulted in grade 2 fractures in 5 specimens and grade 3 in the remaining 5. Dennis classified thoracolumbar fractures into four types: wedge, burst, flexion distraction and fracture dislocation. Burst fractures are further sub-classified into $\mathrm{A}, \mathrm{B}$, and $\mathrm{C}$ depending on whether the fracture involved both endplates or only the upper or the lower end plate [2]. In our series, burst fractures occurred in 9 specimens, while one specimen showed fracture dislocation (specimen 4). In 4 specimens fracture was

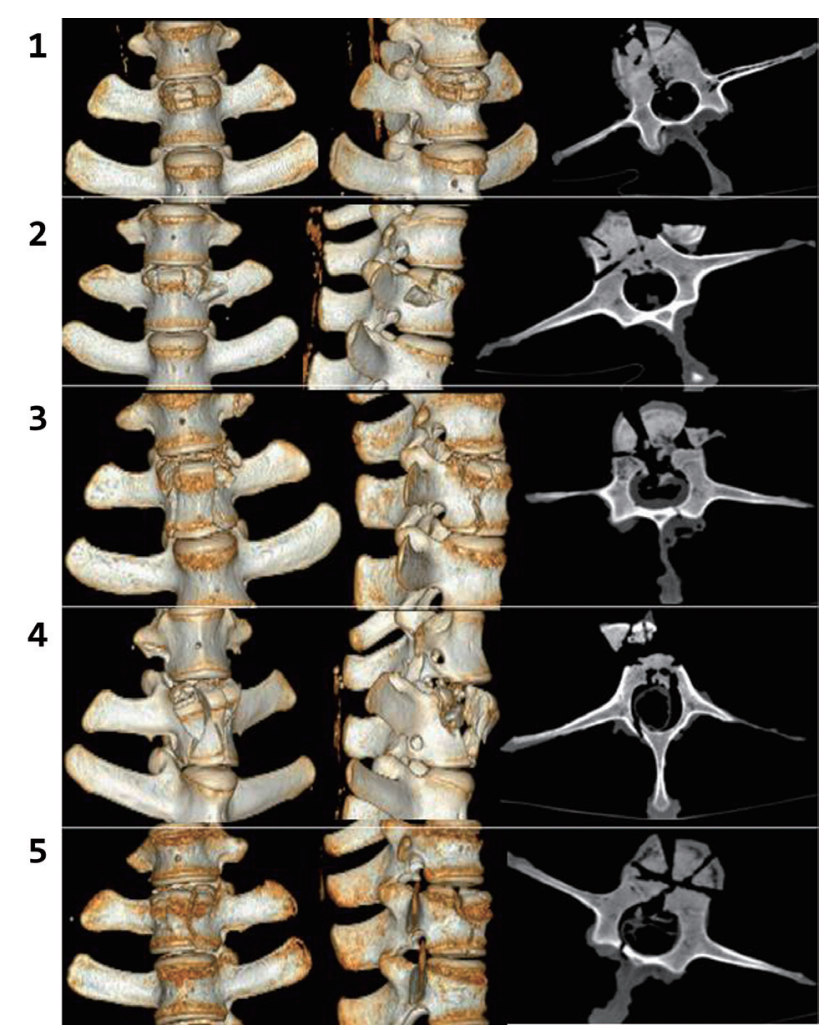

Fig. 4. Three-dimensional reconstruction and the axial computed tomography scan images of the specimens $1-5$ revealing the burst fracture. 
6

7

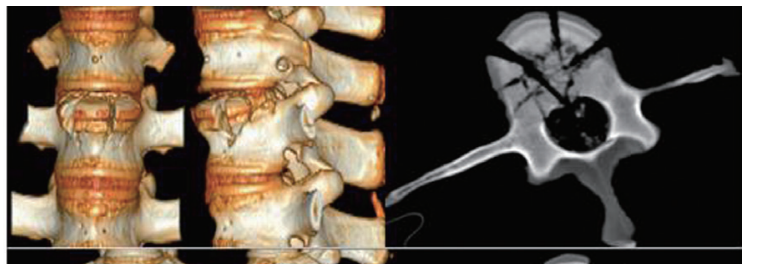

8

9

10
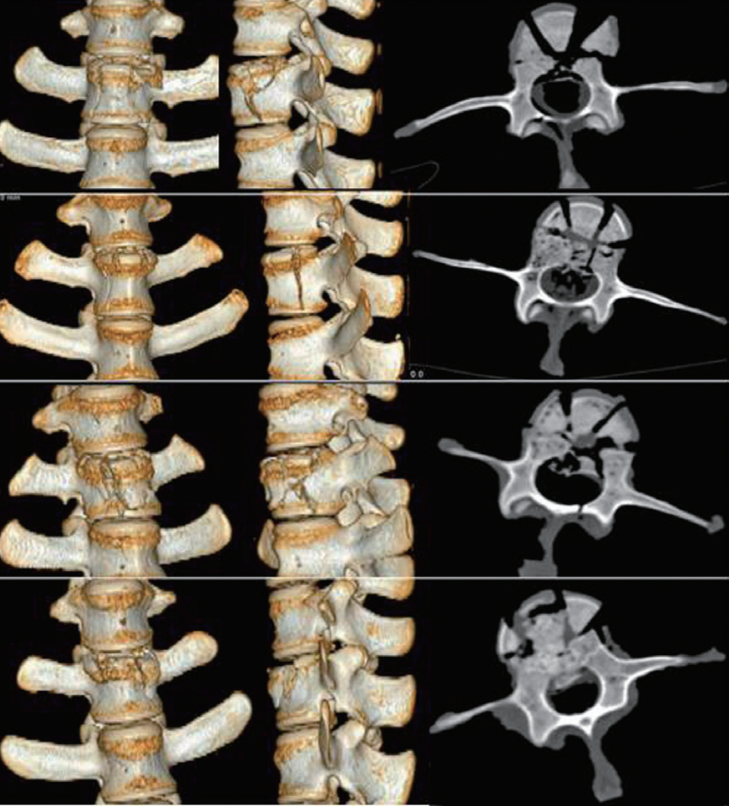

Fig. 5. Three-dimensional reconstruction and the axial computed tomography scan images of the specimens $5-10$ revealing the burst fracture.

limited to upper endplate causing type $2 \mathrm{~B}$ fractures, while the remaining 5 specimens showed fracture extending to the lower end plate resulting in type $2 \mathrm{~A}$ fractures. As per the AO classification [1] 4 specimens showed incomplete burst fractures involving superior endplate representing AO type A3.1.1. Another 4 specimens showed burst fracture in the upper endplate with split in the lower half representing type AO A3.2.1. In 2 specimens, the comminution involved entire vertebral body representing $\mathrm{AO}$ type A3.3.3 fracture. One specimen showed complete burst fracture anteriorly with disruption of posterior ligamentous complex and anterior translation representing AO type B1.2.1+A3.3.3.

\section{Discussion}

Creating a burst fracture is the first step of in vitro biomechanical experiments studying thoracolumbar burst fractures. A variety of methods have been described to create thoracolumbar burst fractures in both human cadaveric and animal spine models. These methods can be classified basically into 3 types-axial compression either by drop weight or by servohydraulic devices, surgical destabilization or a combination of surgical destabilization with axial compression.

Table 2 [7,9-13] summarizes the literature describing the methods of creating thoracolumbar burst fractures in human cadaveric vertebra. Every method has its own advantages and disadvantages. Surgical destabilization alone by fracturing the vertebral body with drill bits do not mimic that occurring naturally because of absence of retropulsion of the fragments of the vertebral body [9]. Moreover, most of these methods involve cutting posterior ligamentous complex or the facet capsule, which is not a feature of typical burst fracture $[9,10]$. Burst fractures by axial compression can be produced by drop weight through a specially designed apparatus or by servohydraulic compressive devices. Servohydraulicdevices can produce high compressive forces but these devices are expensive and not accessible in many centers [7]. Creating burst fractures by a single impact by drop weight alone are ideal methods, mimicking naturally occurring mechanism. However these methods generally involve large weights and the apparatus for dropping them are bulky, have complex designs and are difficult to reconstruct $[11,13]$. Moreover, many of these studies did not have a detailed description of the design of the apparatus or the technique of dropping weight $[11,12]$. Some of these methods protect the non-targeted vertebrae by weakening them, making the specimen unsuitable for further studies [7].

The methods described for creating burst fractures in human cadaveric vertebrae cannot be directly applied to calf spine because of the subtle differences between the two. The calf spine is more rigid and has a lesser range of flexion and extension movement [5]. Hence, flexing the specimen to 10-15 degrees, which is essential for creating burst fractures by axial compression, is difficult to achieve in calf spine. The characteristics of the endplates and the disc of calf spine in comparison to adult human spine have not been studied [7]. In our initial attempts, we found the endplates of calf spine to be more elastic and tough, and difficult to fracture even with larger weights by methods described for human cadaveric spine. Moreover using larger weights resulted in fracture of the vertebral body with intact endplates. We failed to produce burst fractures similar to naturally occurring ones in calf spine by drop weight alone without surgical 
Table 2. Analysis of methods of creating thoracolumbar burst fractures in human cadaveric spine described in the literature

\begin{tabular}{|c|c|c|c|c|c|c|c|}
\hline Study & Method & $\begin{array}{l}\text { Technique } \\
\text { in detail }\end{array}$ & $\begin{array}{l}\text { Sample } \\
\text { size }\end{array}$ & $\begin{array}{l}\text { Analysis } \\
\text { by CT } \\
\text { scan }\end{array}$ & $\begin{array}{c}\text { Consistency } \\
(\%)\end{array}$ & Positives & Negatives \\
\hline Lazaro et al. [9] & $\begin{array}{l}\text { Surgical } \\
\text { destabilisation }\end{array}$ & $\begin{array}{l}\text { All, supra and } \\
\text { interspinous } \\
\text { ligamnets cut and } \\
\text { vertebral body } \\
\text { fractured with thin } \\
\text { cutting drill bit }\end{array}$ & - & No & Nil & $\begin{array}{l}\text { Simple } \\
\text { technique, } \\
\text { no apparatus }\end{array}$ & $\begin{array}{l}\text { Did not mimic } \\
\text { naturally occurring } \\
\text { fractures, } 3 \text { column } \\
\text { injury with damage to } \\
\text { posterior ligaments, } \\
\text { did not produce burst } \\
\text { fractures }\end{array}$ \\
\hline $\begin{array}{l}\text { Hartensuer et al. } \\
\text { [7] }\end{array}$ & $\begin{array}{l}\text { Surgical } \\
\text { weakening } \\
\text { with axial } \\
\text { loading }\end{array}$ & $\begin{array}{l}\text { Standardised } \\
\text { osteotomy cuts } \\
\text { and axial loading } \\
\text { by servohydroolic } \\
\text { device }\end{array}$ & 7 & Yes & 100 & $\begin{array}{l}\text { Produce } \\
\text { naturally } \\
\text { occurring burst } \\
\text { fractures, } \\
\text { consistent }\end{array}$ & $\begin{array}{l}\text { Used expensive } \\
\text { complex hydraulic } \\
\text { device, weakened } \\
\text { other bones fixed } \\
\text { by plate }\end{array}$ \\
\hline $\begin{array}{l}\text { Kallemeier et al. } \\
\text { [10] }\end{array}$ & $\begin{array}{l}\text { Surgical } \\
\text { weakening } \\
\text { and drop weight }\end{array}$ & $\begin{array}{l}\text { Stress raisers by } \\
\text { burr, } 6-8 \mathrm{~kg} \text { of } \\
\text { weight dropped, } \\
\text { repeated until burst } \\
\text { fracture, interspinous } \\
\text { ligaments and facet } \\
\text { capsule cut }\end{array}$ & 9 & Yes & 100 & $\begin{array}{l}\text { Simple } \\
\text { apparatus, } \\
\text { consistently } \\
\text { produced type } \\
\text { B2.1 with } \\
\text { anterior burst }\end{array}$ & $\begin{array}{l}\text { Not typical burst } \\
\text { fracture, posterior } \\
\text { ligaments damaged, } \\
\text { repeated dropping } \\
\text { of weight }\end{array}$ \\
\hline $\begin{array}{l}\text { Fredrickson et al. } \\
\text { [11] }\end{array}$ & Drop weight & $\begin{array}{l}\text { Height of } 1 \mathrm{~m} \text {, } \\
\text { force of } 260-300 \mathrm{~nm}\end{array}$ & 6 & Yes & 100 & $\begin{array}{l}\text { Simple } \\
\text { apparatus }\end{array}$ & $\begin{array}{l}\text { No detailed } \\
\text { description of } \\
\text { apparatus, } \\
\text { technique or fracture } \\
\text { apttern produced, } \\
\text { large weight } \\
\text { (approximately } 30 \mathrm{~kg} \text { ) }\end{array}$ \\
\hline $\begin{array}{l}\text { Mermelstein et al. } \\
\text { [12] }\end{array}$ & $\begin{array}{l}\text { Surgical } \\
\text { weakening with } \\
\text { axial } \\
\text { loading }\end{array}$ & $\begin{array}{l}4.5 \mathrm{~kg} \text { dropped from } \\
1.25 \mathrm{~m} \text { height with } \\
10 \text { degrees flexion } \\
\text { after weakening of } \\
\text { anterior cortex with } \\
\text { osteotome }\end{array}$ & 6 & No & - & Low weight & $\begin{array}{l}\text { Technique, design } \\
\text { of apparatus and } \\
\text { fracture pattern not } \\
\text { described in details }\end{array}$ \\
\hline Jones et al. [13] & Drop weight & $\begin{array}{l}25 \mathrm{~kg} \text { dropped from } \\
\text { a height of } 1 \mathrm{~m} \\
\text { with specimen at } \\
15 \text { degrees flexion } \\
\text { using a specially } \\
\text { designed apparatus }\end{array}$ & 5 & Yes & 100 & $\begin{array}{l}\text { Consistent, } \\
\text { no surgical } \\
\text { weakening, } \\
\text { details of } \\
\text { appataus and } \\
\text { technique } \\
\text { described }\end{array}$ & $\begin{array}{l}\text { Large weight, } \\
\text { complex bulky } \\
\text { apparatus }\end{array}$ \\
\hline
\end{tabular}

CT, computed tomography.

weakening.

Table 3 [7,14-17] summarizes the literature describing the methods of creating a burst fractures in calf spine models. A method described by drop weight alone used a large weight $(100 \mathrm{~kg})$, yet produced burst fractures only in 13 of 24 specimens [14]. Most of the methods employed surgical pre-stressing or osteotomy cuts in the target vertebraprior to axial compression $[7,15]$. Surgical pre-stressing methods again employs larger weights with bulky apparatus. Different methods of osteotomy cuts have been described, but some of these do not produce naturally occurring patterns of the burst fracture [5]. Standardized osteotomy followed by axial compression by servohydraulic devices produced fractures in all the cadaveric specimens, but consistently failed to produce similar fractures in calf spine [7]. 
Table 3. Analysis of methods of creating thoracolumbar burst fractures in calf spine described in the literature

\begin{tabular}{|c|c|c|c|c|c|c|c|}
\hline Study & Method & $\begin{array}{l}\text { Technique } \\
\text { in detail }\end{array}$ & $\begin{array}{l}\text { Sample } \\
\text { size }\end{array}$ & $\begin{array}{l}\text { Analysis } \\
\text { by CT } \\
\text { scan }\end{array}$ & Consistency & Positives & Negatives \\
\hline Cain et al. [14] & Drop weight & $\begin{array}{l}\text { Specially designed } \\
\text { apparatus, } \\
100 \mathrm{~kg} \text { weight } \\
\text { dropped }\end{array}$ & 24 & Yes & 13/24 (54\%) & $\begin{array}{l}\text { Produced } \\
\text { naturally } \\
\text { occurring } \\
\text { burst fracture }\end{array}$ & $\begin{array}{l}\text { Inconsistent, } \\
\text { complex apparatus, } \\
\text { large weight of } \\
100 \mathrm{~kg}\end{array}$ \\
\hline $\begin{array}{l}\text { Hartensuer et al. } \\
\text { [7] }\end{array}$ & $\begin{array}{l}\text { Surgical } \\
\text { weakening } \\
\text { with axial } \\
\text { loading }\end{array}$ & $\begin{array}{l}\text { Standardized } \\
\text { osteotomy cuts and } \\
\text { axial loading by } \\
\text { servohydroolic } \\
\text { device }\end{array}$ & 10 & Yes & $7 / 10(100 \%)$ & $\begin{array}{l}\text { Produce } \\
\text { naturally } \\
\text { occurring } \\
\text { burst fractures }\end{array}$ & $\begin{array}{l}\text { Used expensive } \\
\text { complex hydraulic } \\
\text { device, less } \\
\text { consistent, } \\
\text { weakened other } \\
\text { bones fixed by plate }\end{array}$ \\
\hline $\begin{array}{l}\text { Cotterill et al. } \\
\text { [15] }\end{array}$ & Drop weight & $\begin{array}{l}32 \mathrm{~kg} \text { from height } \\
\text { of } 1.55 \mathrm{~m} \text { with } 15 \\
\text { degrees of flexion of } \\
\text { the specimen after a } \\
5 \mathrm{~mm} \text { slice of the } \\
\text { body and disc }\end{array}$ & 20 & Yes & $100 \%$ & $\begin{array}{l}\text { Consistent, } \\
\text { mimic natural } \\
\text { fractures }\end{array}$ & $\begin{array}{l}\text { Large weight, bulky } \\
\text { complex apparatus }\end{array}$ \\
\hline Wang et al. [16] & $\begin{array}{l}\text { Surgical } \\
\text { weakening } \\
\text { nd drop } \\
\text { weight }\end{array}$ & $\begin{array}{l}V \text { shaped corpectomy } \\
\text { of central part of } \\
\text { body, } 10 \mathrm{~kg} \text { of weight } \\
\text { dropped from } 0.5 \mathrm{~m} \text {, } \\
\text { repeated with } \\
\text { increasing weights }\end{array}$ & 12 & No & $100 \%$ & $\begin{array}{l}\text { Low weight, } \\
\text { simple technique, } \\
\text { consistent }\end{array}$ & $\begin{array}{l}\text { Design of apparatus } \\
\text { not described, not } \\
\text { similar to natural } \\
\text { fracture, repeated } \\
\text { dropping of weights }\end{array}$ \\
\hline Turker et al. [17] & $\begin{array}{l}\text { Compressive } \\
\text { force }\end{array}$ & $\begin{array}{l}\text { Compression by } \\
\text { hydraulic device }\end{array}$ & 11 & Yes & $100 \%$ & $\begin{array}{l}\text { Consistent, } \\
\text { no surgical } \\
\text { weakening, } \\
\text { etails of apparatus } \\
\text { and technique } \\
\text { described }\end{array}$ & $\begin{array}{l}\text { Requires hydraulic } \\
\text { device }\end{array}$ \\
\hline Our study & $\begin{array}{l}\text { Surgical } \\
\text { weakening } \\
\text { and drop } \\
\text { weight }\end{array}$ & $\begin{array}{l}5 \mathrm{~kg} \text { of weight } \\
\text { dropped fram } \\
\text { a specially designed } \\
\text { apparatus after } \\
\text { standardised } \\
\text { osteotomy cuts }\end{array}$ & 10 & Yes & $9 / 10(90 \%)$ & $\begin{array}{l}\text { Low weight, } \\
\text { simple apparatus, } \\
\text { details and design } \\
\text { and technique } \\
\text { described, mimics } \\
\text { natural fractures }\end{array}$ & $\begin{array}{l}\text { Surgical } \\
\text { destabilization }\end{array}$ \\
\hline
\end{tabular}

CT, computed tomography.

We describe a method of creating burst fracture in calf spine by standardized osteotomy cuts followed by drop weight. Osteotomy cuts extended to the posterior body wall and the fragments were retropulsed following drop weight, which mimicked naturally occurring burst fractures. The drop weight device had a simple design and was constructed at a local workshop from easily available materials. We employed a low weight and the impact at the anterior aspect of the specimen ensured that the force was transmitted to vertebral bodies preserving the facets and the posterior ligamentous complex. It also created vertical laminar split fractures in 6 specimens, which is char- acteristic of burst fractures. Disruption of the posterior ligamentous complex with facet subluxation and anterior translation occurred in one specimen, which was possibly due accidental posterior slipping of the point of impact, loading the facets.

\section{Conclusions}

We describe a simple technique of creating thoracolumbar burst fractures in a calf spine model. The technique involves low weight and the apparatus used for dropping weight can be easily constructed. The fractures produced 
mimic those occurring naturally and can be reproduced consistently. This can be considered as an alternative technique for biomechanical experiments studying burst fractures.

\section{Conflict of Interest}

No potential conflict of interest relevant to this article was reported.

\section{References}

1. Magerl F, Aebi M, Gertzbein SD, Harms J, Nazarian S. A comprehensive classification of thoracic and lumbar injuries. Eur Spine J 1994;3:184-201.

2. Holdsworth F. Fractures, dislocations, and fracturedislocations of the spine. J Bone Joint Surg Am 1970; 52:1534-51.

3. Denis F. The three column spine and its significance in the classification of acute thoracolumbar spinal injuries. Spine (Phila Pa 1976) 1983;8:817-31.

4. Fakurnejad S, Scheer JK, Patwardhan AG, Havey RM, Voronov LI, Smith ZA. Biomechanics of thoracolumbar burst fractures: methods of induction and treatments. J Clin Neurosci 2014;21:2059-64.

5. Wilke HJ, Krischak ST, Wenger KH, Claes LE. Loaddisplacement properties of the thoracolumbar calf spine: experimental results and comparison to known human data. Eur Spine J 1997;6:129-37.

6. Swartz DE, Wittenberg RH, Shea M, White AA 3rd, Hayes WC. Physical and mechanical properties of calf lumbosacral trabecular bone. J Biomech 1991; 24:1059-68.

7. Hartensuer R, Gasch A, Gehweiler D, et al. Experimentally induced incomplete burst fractures: a novel technique for calf and human specimens. BMC Musculoskelet Disord 2012;13:45.

8. McCormack T, Karaikovic E, Gaines RW. The load sharing classification of spine fractures. Spine (Phila
Pa 1976) 1994;19:1741-4.

9. Lazaro BC, Deniz FE, Brasiliense LB, et al. Biomechanics of thoracic short versus long fixation after 3-column injury. J Neurosurg Spine 2011;14:226-34.

10. Kallemeier PM, Beaubien BP, Buttermann GR, Polga $\mathrm{DJ}$, Wood KB. In vitro analysis of anterior and posterior fixation in an experimental unstable burst fracture model. J Spinal Disord Tech 2008;21:216-24.

11. Fredrickson BE, Edwards WT, Rauschning W, Bayley JC, Yuan HA. Vertebral burst fractures: an experimental, morphologic, and radiographic study. Spine (Phila Pa 1976) 1992;17:1012-21.

12. Mermelstein LE, McLain RF, Yerby SA. Reinforcement of thoracolumbar burst fractures with calcium phosphate cement: a biomechanical study. Spine (Phila Pa 1976) 1998;23:664-70.

13. Jones HL, Crawley AL, Noble PC, Schoenfeld AJ, Weiner BK. A novel method for the reproducible production of thoracolumbar burst fractures in human cadaveric specimens. Spine J 2011;11:447-51.

14. Cain JE Jr, DeJong JT, Dinenberg AS, Stefko RM, Platenburg RC, Lauerman WC. Pathomechanical analysis of thoracolumbar burst fracture reduction: a calf spine model. Spine (Phila Pa 1976) 1993;18:164754.

15. Cotterill PC, Kostuik JP, Wilson JA, Fernie GR, Maki BE. Production of a reproducible spinal burst fracture for use in biomechanical testing. J Orthop Res 1987;5:462-5.

16. Wang H, Li C, Liu T, Zhao WD, Zhou Y. Biomechanical efficacy of monoaxial or polyaxial pedicle screw and additional screw insertion at the level of fracture, in lumbar burst fracture: an experimental study. Indian J Orthop 2012;46:395-401.

17. Turker M, Tezeren G, Tukenmez M, Percin S. Indirect spinal canal decompression of vertebral burst fracture in calf model. Arch Orthop Trauma Surg 2005;125:336-41. 